\title{
Studying the Antimicrobial Activity of Tamarind Extract (Tamarindus indica L.)
}

\author{
Saher S. George Shamaail A. Saewan Rawdhah M. Ali \\ Department of Food science, College of Agriculture, University of Basrah, Iraq
}

\begin{abstract}
The present study included the preparation of Tamarindus indica extract (pulp and seeds) at different concentrations $(25,50,70$ and 100) $\mathrm{mg} \backslash \mathrm{ml}$ in the manner of $1: 1$ water -alcohol extraction. To determine the sensitivity of some positive and negative Gram bacteria to the different concentration mentioned above of the extract such as E.coli, Pseudomonas, Staph aureus, Bacillus ceres compared with antimicrobial Ampicillin, Tetracycline and Amoxicillin. Concentration of $100 \mathrm{mg} \backslash \mathrm{ml}$ gave the highest rates of inhibition (22, 19, 18 and 17 $\mathrm{mm}$ ) for the pulp extract respectively and for the same previous arrangement of the bacteria, while the diameter of the transparent halo decreased with the reduction of concentration of the tamarind extract compared with the control treatment, its inhibition was $5 \mathrm{~mm}$. On the other hand, the results of tamarind seed extract showed the highest inhibition for all types of bacteria used in the experiment with the highest rates of inhibition diameters (21, 22,25 and $17 \mathrm{~mm}$ ) for the highest concentration $100 \mathrm{mg} \backslash \mathrm{ml}$ and the previous bacteria sequence. Tetracycline was given the highest rates of inhibition of bacteria in the same order $(30,24,28$ and $25 \mathrm{~mm})$ respectively, while no inhibitory effect was observed for Ampicillin and Amoxicillin.
\end{abstract}

Keywords: antimicrobial, Tamarind extract, antibiotics

DOI: $10.7176 /$ FSQM/90-04

Publication date:September $30^{\text {th }} 2019$

\section{Introduction}

Tamarinds indica belongs to the legume, a corpus of horny of a rapidly growing evergreen tree (Kumar and Bhattacharya, 2008). The Tamarinds plant consists about $30-50 \%$ pulp, 11-30\% shell and 25- 40\% seeds (ElSiddig et al., 2006). They are becoming more important due to their used to treat different disease disturbed digestive systems dipteral and other disease (Diapali et al., 2010).

Food contaminated by different microbes that effect the food become unsecure health, for that reason many chemical types used as preservative for example acetic acid, lactic, ascorbic and benzoic acid .These acids are acumen lactase in the materials which become harmful. The used of plant extract are and more save to used in food (Chen et al., 2013). For that reason the health environment control groups were materials for more save and secure. (Gupta et al.2010).

There were also side effect of antibiotics used to mix different strains of pathogenic may have a negative effect. Recent studies have given great importance to use alternatives to plant extract in inhibition (Cowan,1999).

bacterial because they contain chemical compounds that Tamarinds fruit is one of these fruits which is containing high percentage of the activity material for example organic acid (citric, tartaric and malic acid); potassium citrate and minerals (phosphorus, magnesium, iron, manganese, calcium, sodium, chlorine; also vitamin B3 and volatile oil also it contains antibacterial for different kinds of bacterial (El-Siddig et al., 2006). The present study aimed at using extraction of Tamarind plant with antimicrobial activity, including positive and negative bacteria and comparing with antibiotics for their great importance present in order to use their extraction in food preservation, inhibition of pathogenic bacteria and in preserving the public health of the individual in our society.

\section{Martials and methods}

2.1 Tamarind extraction:

Tamarind fruits were brought from Basrah market. The pulp was hands crapped from the seeds .The pulp and crushed seed were dried at $40 \mathrm{C}^{\circ}$ for 72 hours. Then $100 \mathrm{~g}$ of each were soaked with $400 \mathrm{ml}$ of water-alcohol solution $(1: 1)$ and left for 24 hours in the refrigerator with intermittent shaking. The mixtures were centrifuged at 3500r for $20 \mathrm{~min}$. and finality filtered through what Mann filter paper No. 1 (Azoro, 2000) The supernatant were collected and concentrated under pressure in a rotary vacuum evaporate until semisolid residue were obtained according to the method mention by (Martinello et al., 2006). There were dried inside the crucible under to obtain solid powder (Jonathan and Fasidi, 2003). One gram from each pulp and crush seeds powder extraction were dissolved by $5 \mathrm{ml}$ of alcohol solution $(1: 1)$. These stokes solution become as $100 \%$ concentrate extraction. Different concentration levels $25,50,75$ and $100 \mathrm{mg} / \mathrm{ml}$ were prepared from pulp and seed crushed solution extraction.

\section{2 phytochemical analysis}

The phytochemical tests were performed using various reagents. The purity of polysaccharide was determined by prescribed phytochemical tests, which indicated the absence of tannins, alkaloids, flavonoids, sugars, steroids, 
phenols and saponins (Molan,1992).

\subsection{Antibacterial activity}

The propagation method was used on the center of Mueller-Hinton Agar (Okeke et al., 2001). The pure isolates were activated for types of Gram positive and negative bacteria are E.coli, Pseudomonas ,Staph aureus, Bacillus ceres in Nutrient broth medium Oxoid.

Antibacterial activity was test for the efficiency of antibacterial agents in the pulp and crushed seed extraction concentration and compared with amoxicillin, ampicillin, tetracycline and control. Pseudomonas; Bacillus; E. coli and Staph aureus were used as test microorganisms.

They were activated in nutrient broth by fermentation at $37 \mathrm{C}^{\circ}$ for 24 hours. A loop full of the bacteria that activated and enriched in nutrient broth were transferred to pepton water and emulsified to turbidity of McFarland 0.5 density. The final bacterial cell concentration approximated to $10^{8} \mathrm{~g}$ cfu $/ \mathrm{ml}$. leave the dishes to dry for $5-10$ minutes after which the hole was pierced with $5 \mathrm{~mm}$ diameter hole and 50 microliters of the prepared concentrations of tamarind pulp and seed extract $(100,75,50$ and $25 \mathrm{mg} / \mathrm{ml})$ were placed in each hole. The control was only soul of alcohol solution $(1: 1)$. The dishes were then incubated at $37 \mathrm{C}^{\circ}$ for 24 hours and the inhibitory diameter was measured for each treatment (Gupta et al., 2014). The test for inhibition of the samples obtained from pulp and seed extraction in relation to antibiotic and control was carried out with three repetitions. The average of the results for each were compared statistically.

\subsection{Statistical analysis}

Data in current study were subject to one-way analysis of variance (ANOVA) using XL Stat program for Windows. Differences Between the means were tested by Duncan's multiple range tests. The level of significance was chosen at $\mathrm{P}<0.05$ and the results are presented as mean (Steel et al., 1996).

\section{Results and Discussions}

Phytochemical evaluation of pulp fruit extract Table 1 show the phytochemical screening of the tamarind pulp fruit extract . then samples revealed only tannins and flavonoids were positive, the tannins are mostly responsible for antioxidant properties and flavonoids are responsible for other properties . and all reagents are negative in these results . this results agreement with (GHONGADE, 2013).

Table 1 : Phytochemical evaluation of pulp fruit extract

\begin{tabular}{|c|c|}
\hline phytoconstituent & results \\
\hline Steroids & - \\
\hline Tannins & + \\
\hline Alkaloids & - \\
\hline Spanning & - \\
\hline Flavonoids & + \\
\hline Glycoside & - \\
\hline Protein and amino acid & - \\
\hline
\end{tabular}

Table 2 showed significant differences $(\mathbf{p}>\mathbf{0 . 0 5})$ between the region of microbial inhibition zones of the different treatment.

Table (2) Effect of tamarinds fruits extract and antibiotics on pathogenic bacteria inhibitory

\begin{tabular}{|l|c|c|c|c|c|c|c|c|}
\hline $\begin{array}{l}\text { Type } \\
\text { Tyen }\end{array}$ & Control & 25 & 50 & 75 & 100 & Amoxicillin & Ampicillin & Tetracycline \\
\hline Pseudomonas & $5^{\mathrm{i}}$ & $7^{\text {ghi }}$ & $9^{\mathrm{f}}$ & $15^{\mathrm{e}}$ & $17^{\mathrm{de}}$ & $5^{\mathrm{i}}$ & $5^{\mathrm{i}}$ & $25^{\mathrm{b}}$ \\
\hline Bacillus & $5^{\mathrm{i}}$ & $8^{\mathrm{fgh}}$ & $10^{\mathrm{f}}$ & $15^{\mathrm{e}}$ & $19^{\mathrm{d}}$ & $5^{\mathrm{i}}$ & $5^{\mathrm{i}}$ & $24^{\mathrm{bc}}$ \\
\hline E.coli & $5^{\mathrm{i}}$ & $6^{\mathrm{hi}}$ & $10 \mathrm{f}$ & $15^{\mathrm{e}}$ & $18^{\mathrm{d}}$ & $5^{\mathrm{i}}$ & $5^{\mathrm{i}}$ & $28^{\mathrm{a}}$ \\
\hline Staph aureus & $5^{\mathrm{i}}$ & $8^{\mathrm{fgh}}$ & $15^{\mathrm{e}}$ & $18^{\mathrm{d}}$ & $22^{\mathrm{c}}$ & $5^{\mathrm{i}}$ & $5^{\mathrm{i}}$ & $30^{\mathrm{a}}$ \\
\hline \multicolumn{7}{|c|}{$\%$ of inhibitory } \\
\hline Pseudomonas & - & 40 & 80 & 200 & 240 & - & - & 400 \\
\hline Bacillus & - & 60 & 100 & 200 & 280 & - & - & 380 \\
\hline E.coli & - & 20 & 100 & 200 & 260 & - & - & 460 \\
\hline Staph aureus & - & 60 & 200 & 260 & 340 & - & - & 500 \\
\hline
\end{tabular}

Means with different letters in the same are significantly different $(\mathrm{p}<0.05)$ for each sample

The a gradual were increased of pulp extracted 25,50,75 and $100 \mathrm{mg} \backslash \mathrm{ml}$ as compared with the control were $8,15,18,22 \mathrm{~mm}$. The best effected at $100 \mathrm{mg} \backslash \mathrm{ml}$. Staph aureus in the diameter of the inhibition area zones as compared with Pseudomonas, Bacillus, E.coli and the control. Staph aureus had a highly significant effectiveness at $100 \mathrm{mg} \backslash \mathrm{ml}$ concentrated to all microbial diameter inhibition $(\mathrm{mm})$ percentage. It was $340 \%$ as compared with 280\%, 260\%, 240\% and zero Bacillus, E.coli, Pseudomonas and the control respectively. Table 2 also showed a 
significantly differences in the rates of tetracycline diameter inhibitors area to Staph aureus as compared with E.coli, Pseudomonas, Bacillus and the control while there was no inhibition of the Ampicillin and Amoxicillin antibiotic used in the inhibition diameter parentage to the tetracycline was $500 \%$ as compared with $460 \%$, 400\%, $380 \%$ and zero in the following image 1 showed diameter $(\mathrm{mm})$ the inhibition area of E.coli, Pseudomonas, Bacillus and Staph aureus. These results were in agreement with Gumgumjee et al., (2012) who indicated that the tamarinds leaves extract inhibited effectiveness $(25,15,15$ and $20 \mathrm{~mm})$ to bacteria Pseudomonas aeruginosa, E. coli, Staph aureus and Bacillus sutilis respectively. Abdul Kapur and Ahmed John (2014), indicated that the extract of tamarind plant has anti-bacterial positive and negative effects suggested that organic acids, hydrogen peroxide and other substances were responsible for the inhibition. The results in table 2 showed the inhibitory effect of the extract of seeds of tamarind, which increased significantly by increasing the concentration of $100 \mathrm{mg} \backslash \mathrm{ml}$ gave the highest significant difference $(\mathrm{p}>0.05)$ in the trans of inhibition $25 \mathrm{mg} \backslash \mathrm{ml}$ of Staph aureus bacteria as compared with other 22, 21, 17 and zero mm diameters inhibition to Pseudomonas, E.coli, Bacillus and control, then image 2 showed diameter $(\mathrm{mm})$ the inhibition area at seed extraction.
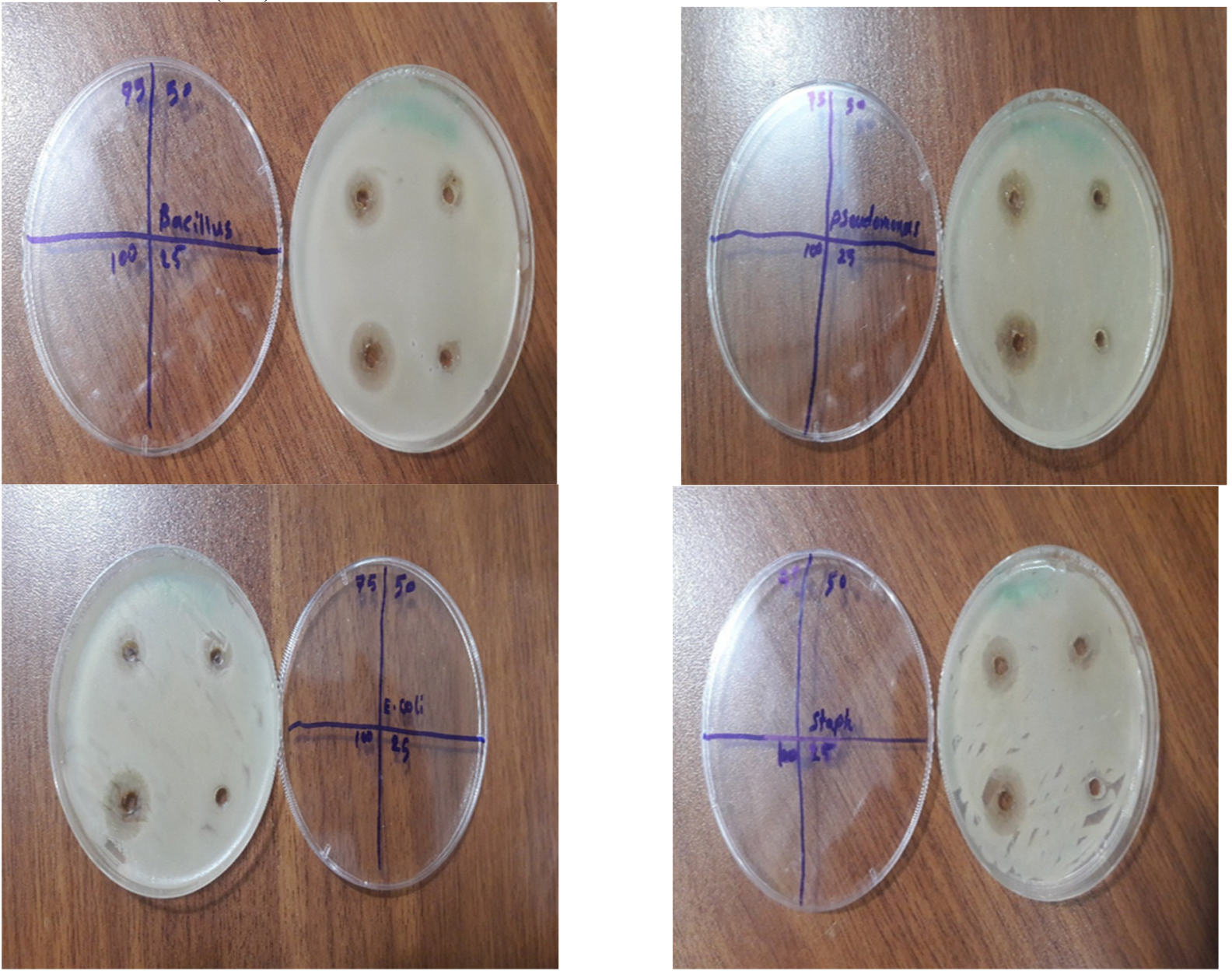

Figure (1) the effect of different concentrations of tamarind extract on pathogenic bacteria

Abdul kapur and Ahmed john (2014) indicated that the pulp and seed extract in diameter (mm) of the inhibition of all bacteria may be due to the inhibition of the presence of antibacterial compounds found in the pulp of fruits and seeds tamarind likes saponins, glycosides, alkaloids work of enzyme. In addition to be working to formation of complexes with sugar and citric acid is one of the main components of the tamarind, which has the ability to reduce the $\mathrm{pH}$, which prevents the absorption of essential nutrients by microorganism and thus get a change in the permeability of cell wall, the death time of bacteria (cowan, 1999).

In seed extract treatment may be due to active ingredients in tamarind seeds, it contained pectin and polysaccharides by $46-48 \%$ which is one of the main reasons that increase of the antimicrobial activity as well as containing tartaric acid which increases the acidity of the extract and thus the inhibitory effect of microbes (ELSidding et al., 2006). When compared the extracts of the pulp and the tamarind seeds, it was observed that extract of tamarind seeds gave the best rates of inhibition in comparison with the pulp extract on all species of bacteria. This may be due to containing the seeds on palmatic acid, fatty acid (14-20) \%, oleic (15-27) \% and linoleic acid $(36-49) \%$. These acids are the most important antioxidants that increase antibacterial active (khairunnuur et al., 2009). 
Table (3) Effect of tamarind seeds extract and antibiotics on pathogenic bacteria inhibitor

\begin{tabular}{|l|c|c|c|c|c|c|c|c|}
\hline $\begin{array}{l}\text { Con } \\
\text { type }\end{array}$ & Control & 25 & 50 & 75 & 100 & Amoxicillin & Ampicillin & Tetracycline \\
\hline Pseudomonas & $5^{\mathrm{i}}$ & $16^{\mathrm{gi}}$ & $18^{\mathrm{fgh}}$ & $20^{\mathrm{def}}$ & $22^{\mathrm{cd}}$ & $5^{\mathrm{i}}$ & $5^{\mathrm{i}}$ & $25^{\mathrm{b}}$ \\
\hline Bacillus & $5^{\mathrm{i}}$ & $12^{\mathrm{k}}$ & $13^{\mathrm{f}}$ & $15^{\mathrm{ij}}$ & $17^{\mathrm{ghi}}$ & $5^{\mathrm{i}}$ & $5^{\mathrm{i}}$ & $24^{\mathrm{bc}}$ \\
\hline E.coli & $5^{\mathrm{i}}$ & $13^{\mathrm{jk}}$ & $16^{\mathrm{hi}}$ & $19^{\mathrm{egh}}$ & $21^{\mathrm{de}}$ & $5^{\mathrm{i}}$ & $5^{\mathrm{i}}$ & $28^{\mathrm{a}}$ \\
\hline Staph aureus & $5^{\mathrm{i}}$ & $18^{\mathrm{fgh}}$ & $20^{\mathrm{def}}$ & $22^{\mathrm{cd}}$ & $25^{\mathrm{b}}$ & $5^{\mathrm{i}}$ & $5^{\mathrm{i}}$ & $30^{\mathrm{a}}$ \\
\hline \multicolumn{7}{|c|}{$\%$ of inhibitory } \\
\hline Pseudomonas & - & 220 & 260 & 300 & 340 & - & - & 400 \\
\hline Bacillus & - & 140 & 160 & 200 & 240 & - & - & 380 \\
\hline E.coli & - & 160 & 220 & 280 & 320 & - & - & 460 \\
\hline Staph aureus & - & 260 & 300 & 340 & 400 & - & - & 500 \\
\hline
\end{tabular}

Means with different letters in the same are significantly different $(\mathrm{p}<0.05)$ for each sample

Table 3 shows the effect of the different concentration levels of the alcoholic water extract of the sour tamarind pulp $(25,50,75$ and 100$) \mathrm{mg} \backslash \mathrm{ml}$ to test effectiveness against the sensitivity of both positive and negative gram bacteria. The results showed that all the levels of concentrations used in the experiment gave a graduated positive effect of all gram positive and negative bacteria, Staph aureus, Baciasllus, Pseudomonas and E. coli. Gumgumjee et al. (2012) indicated that the tamarindus indica leaves extract inhibited effectiveness $(25,15,15$ and 20) $\mathrm{mm}$ of the bacteria Pseudomonas aeruginosa, E.coli, Staph aureus and Bacillus subitis respectively. The results also showed that Staph aureus bacteria had significantly effectiveness $(\mathrm{p}>0.05)$ as compared with other bacteria. The pulp extraction of $100 \%$ concentrations increasing order for Staph aureus, Bacillus, Pseudomonas and $E$. coli. It showed that 340,280, 260 and 200 respectively inhibitory decreased effectiveness compared with other concentrations the effectiveness of some antibiotics are decreased of growth different types of bacteria Saga and Yamaguchi,2009).Then the 100 concentrated had more significantly effect on the increasing inhibitory by $240 \%$ as compared with 280,260, 240 and zero to Baciasllus, Pseudomonas E.coli and control respectively this way agree with the finding as Ahulkiapur and Ahmed (2014) who indicated that the extract at the tamarind plant has anti- bacteria positive and negative effect of their bacteria.

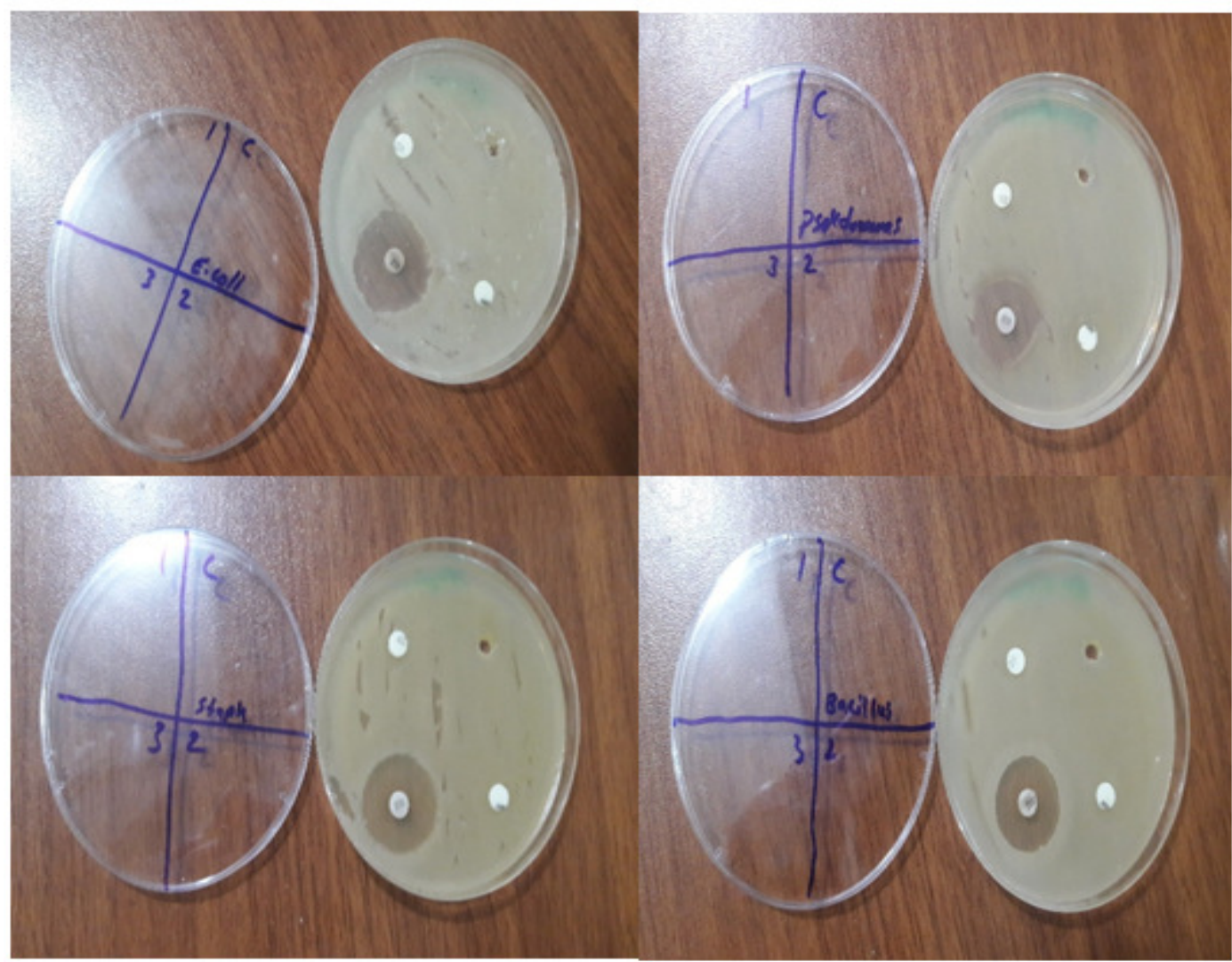

Figure (2) Effect of antibiotic and control treatment on pathogenic bacteria

the conclusion from this study that tamarind seeds extract and the pulp extract were associated with antagonistic mechanisms against the pathogens bacteria. 


\section{References}

Abdul Kapur, M and Ahmed John, S. (2014), "Antimicrobial Activity of Ethanolic Bark Extract of Tamarindus indica against some Pathogenic Microorganisms”,Int.J.Curr.Microbiol.App.Sci., 3(3): 589-593.

Azoro, C. (2000) , "Antibacterial activity of crude extract of Azadirachita indica on Salmonella typhi”, World Journal of Biotechnology, 3: 347-351.

Chen, J.; Deng, S. and Li, J. (2013), "Preparation of an novel botanic biopreservative and its efficacy in keeping quality of peeled Penaeus vannamei”, Food Science and Technology International, 19: 251-60.

Cowan, M. M. (1999), “ Plant products as antimicrobial agents”, Clin. Microbial. Rev., 12(4): 564 - 582.

Dipali, Y. J. ; Akshaya, K. S.; Jai, S. G.; Rahul, C. R. and Aruna, M. M.(2010), "Phytochemical detection and in vitro evaluation of Tamarind fruit pulp for potential anti activity", International Journal of Tropical Medicine, 5(3):68-72.

El-Siddig, K.; Gunasena, H. P. M.; Prasa, B. A.; Pushpakumara, D. K. N. G.; Ramana, K. V. R., Vijayan, P. and Williams, J. T. (2006), "Tamarind - Tamarindus indica L. Fruits for the future 1", Southampton Centre for Underutilized Crops, Southampton, UK, 188p.

GHONGADE, R. (2013), " Phytochemical analysis of citrus karna fruit”, Int J Pharm Bio Sci ., 4(2): (B) 1162 1167.

Gumgumjee, N. M; Khadr, A. and Hajarm, S. A. (2012), "Antimicrobial activities and chemical properties of Tamarindus indica L. leaves extract”, African Journal of Microbiology Research. 6(32):6172-6181.

Gupta, C.; Garg, A. P. and Gupta, S. (2010), "Antimicrobial and Phytochemical studies of fresh ripe pulp and dried unripe pulp of Mangifera indica (Amchur) ", Middle- East Journal of Scientific Research, 5: 75-80.

Gupta, C.; Prakash, D. and Gupta, S. (2014), "Studies on the antimicrobial activity of Tamarind (Tamarindus indica) and its potential as food bio-preservative", International Food Research Journal, 21(6): 2437-2441.

Jonathan, S. G. and Fasidi, I.O. (2003), "Antimicrobial activities of two Nigerian edible macro fungi - Lycoperdon pusilum (Bat. Ex) and Lycoperdon giganteus", (Pers).African J. Biomed. Research, (6): 85 - 90.

Khairunnuur, F. A.; Zulkhairi, A.; Azrina, A.; Moklas, M. A. M. and Khairullizam, S. (2009) , " Nutritional composition, in vitro antioxidant activity and Artemia salina L. lethality of pulp and seed of Tamarindus indica L.", extracts. Mal. J. Nutr., 15(1): 65-75.

Kumar, C. S. and Bhattacharya, S. (2008), “ Tamarind Seed: Properties, Processing and Utilization”, Critical Reviews in Food Science and Nutrition, 48: 1-20.

Martinello, F.; Soares, S. M.; Franco, J. J.; Santos, A. C.; Sugohara, A.; Sugohara, S. B.; Curti, C. and Uyemura, S. A. (2006), " Hypolipemic and antioxidant activities from Tamarindus indica L. pulp fruit extract in hypercholesterolemic hamsters",. Food and Chemical Toxicology, (44): 810-818.

Molan, P.C.( 1992), "The nature of antibacterial activity", Bee World, 73: 59-76

Okeke, M. I.; Iroegbu, C. U.; Eze, E. N.; Okoli, A. S. and Esimone, C. O. (2001), "Evaluation of extracts of the root of Landolphia owerrience for antibacterial activity", Journal of Ethno pharmacology, 78: 119-127.

Saga, T. and Yamaguchi, K. (2009), "History of antimicrobial agents and resistant bacteria”, JMAJ., 52(2):103108.

Steel, R. G. D.; Torrie, J. H. and Dickey, D. A. (1996), "Principles and procedures of statistics", A biometrical approach. $3^{\text {rd }}$ ed. McGraw Hill Book Company Inc, New York, USA. 